\title{
Religions, droit et sociétés dans l'Europe communautaire (cf. Arch. supra. Nathalie Luca)
}

Actes du XIIIe colloque de l'Institut de Droit et d'Histoire Religieux (IDHR), Aix-en-Provence 19-20 mai 1999, Presses universitaires d'AixMarseille, 2000, 294 p. (cf. Arch. supra, pp. 31-37).

\section{(2) OpenEdition}

Journals

Édition électronique

URL : http://journals.openedition.org/assr/1454

DOI : $10.4000 /$ assr. 1454

ISSN : $1777-5825$

Éditeur

Éditions de l'EHESS

Édition imprimée

Date de publication : 1 avril 2003

ISBN : 2-222-96732-5

ISSN : 0335-5985

Référence électronique

«Religions, droit et sociétés dans l'Europe communautaire (cf. Arch. supra. Nathalie Luca) », Archives de sciences sociales des religions [En ligne], 122 | avril - juin 2003, document 122.90, mis en ligne le 10 novembre 2005, consulté le 23 avril 2019. URL : http://journals.openedition.org/assr/1454; DOI : 10.4000/assr. 1454

Ce document a été généré automatiquement le 23 avril 2019

Archives de sciences sociales des religions 


\section{Religions, droit et sociétés dans} l'Europe communautaire (cf. Arch. supra. Nathalie Luca)

Actes du XIIIe colloque de l'Institut de Droit et d'Histoire Religieux (IDHR), Aix-en-Provence 19-20 mai 1999, Presses universitaires d'AixMarseille, 2000, 294 p. (cf. Arch. supra, pp. 31-37). 